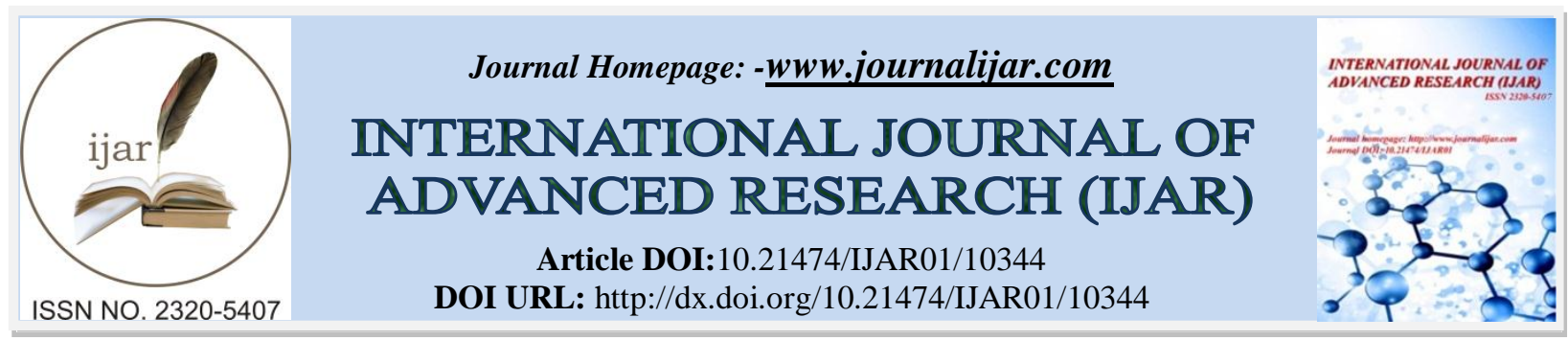

RESEARCH ARTICLE

\title{
RECONSTRUCTION OF THE ROLE OF THE INDONESIAN NATIONAL POLICE FORENSIC LABORATORY IN A CRIMINAL JUSTICE SYSTEM BASED ON JUSTICE VALUE
}

\author{
Gunarto $^{1}$, Teguh Prihmono ${ }^{2}$ and Sri Endah Wahyuningsih ${ }^{1}$ \\ 1. Faculty of Law Universitas Islam Sultan Agung Semarang, Indonesia. \\ 2. Doctorate Student of Faculty of Law Universitas Islam Sultan Agung Semarang, Indonesia.
}

\section{Manuscript Info}

.1.........................

Manuscript History

Received: 27 November 2019

Final Accepted: 30 December 2019

Published: January 2020

Key words:-

Reconstruction, Indonesian National

Police, Forensic Laboratory, Justice Value

\section{Abstract}

The role of the Indonesian National Police forensic Laboratory has contributed to legal certainty, but at present it is not yet based on the value of justice, influencing factors include understanding the substance of letters and expert statements in article 184 (1) of the Criminal Procedure Code is multi-interpretation, the base of the Indonesian National Police forensic Laboratory is still limited, the empowerment of the Indonesian National Police forensic Laboratory has not been maximized so that several problems arise, for example there are investigators not familiar with, understand the empowerment of the Indonesian National Police forensic Laboratory, technical issues and other problems. Formulation of the problem: (1) Why is the role of the Indonesian National Police forensic laboratory in the criminal justice system currently not based on the value of justice (2) What are the weaknesses that arise in the implementation of the role of the Indonesian National Police forensic Laboratory in the criminal justice system not based on the value of justice and (3) How is the reconstruction of the role of the Indonesian National Police Forensic Laboratory in the criminal justice system based on justice values with an empirical juridical research approach. The results of this study are the legal reconstruction of the substance of substance in Article 184 (1) of Law No.8 of 1981 concerning Criminal Procedure Law, the legal evidence being 6 (six) items, namely witness statements, expert statements, letters, instructions statement of the defendant and the results of the forensic Laboratory examination; reconstruction of structural elements, namely in each Polda and large cities, the Indonesian National Police forensic Laboratory was built and reconstruction of the cultural element, which was to empower the forensic Laboratory with the strategy of the results of the forensic Laboratory examination included in item 6 (six) in Evidence, Article 184 ( 1) The Criminal Procedure Code is expected that the public, legal practitioners and academics will change their mindset into a new paradigm and expect the state to facilitate the role of an ideal forensic laboratory so that in the end its role is based on the value of justice. 


\section{Introduction:-}

The Indonesian National Police Forensic Laboratory is part of the criminal justice sub-system which has the task of examining evidence in a technically criminalistic manner at the scene of the case as well as criminalistic laboratories through scientific methods so far its existence is very supportive for legal certainty and the value of justice.The role of the Indonesian National Police Forensic Laboratory starts from the investigation stage to the stage of determining the case in court, as evidence in the form of letters and expert statements (Indonesian criminal procedure code Article 184), but in its implementation sometimes becomes biased / multiple interpretations on the understanding of the substance of expert statements and letters, As a result, it has a cultural impact, besides that the factor which also has a big influence on culture is the structural factor, because the construction of Indonesian National Police Forensic Laboratory bases throughout Indonesia has only 7 (seven) construction of Forensic Laboratory bases, each of which has a service area, with limited Laboratory infrastructure Forensics can make the cause less socialized to investigators in particular so that it affects the culture / empowerment of forensic laboratories, from problems to the substance, structure and culture in general, including :

1. There are still investigators who do not know much less let alone understand the Indonesian National Police Forensic Laboratory Institution that can be optimally empowered in finding and gathering evidence at the crime scene.

2. There are still many investigators in looking for and collecting evidence that does not / does not involve forensic laboratories, this will be a problem both formally and technically, because the evidence related to criminal acts is solid, liquid and gas, and can be dangerous so it needs special handling from each of the properties of the object or evidence.

3. There are still investigators who have not mastered the technical procedures for handling evidence. Many pieces of evidence that are on the scene of a crime are dangerous, for example: toxic, corrosive, irritant, infection, explosive and others. Therefore, in the search, take, wrap, carry and store until finally arriving at the forensic laboratory, requires technical procedures that must be passed. That is why investigators as well as examiners from forensic laboratories must master the technical procedures for handling evidence. If the technical procedures in handling evidence are not maximally and correctly passed, the results of the examination in the laboratory will also not be optimal and correct, ultimately the objective of the investigation is not achieved, which is to make light of a case and will also endanger individual personnel, teams, unity and the community.

4. The distance factor between the Indonesian National Police forensic Laboratory base and regional units, for example the Makassar branch of the Indonesian National Police forensic laboratory with service area to Papua, can cause its own constraints related to the security system applied in aviation such as explosive evidence, liquids, firearms , etc., so that the journey is taken by sea and land transportation so it takes a long time and results in investigation administration.

5. The ability of some Indonesian National Police forensic Laboratory personnel is not evenly distributed in terms of science and technology. The ability of Indonesian National Police Forensic Laboratory personnel must always be aptudate along with the development of developing technology.

6. Instruments / special tools / modern tools used for examination of evidence as the main pillar supporting scientific investigations are still not maximally fulfilled.

7. Facilities and infrastructure of the Forensic Laboratory building in certain parts are still not optimal.

8. Sometimes forensic laboratory results are maximally empowered, but in the end they are not used as evidence because of certain situations and conditions.

With the conditions stated above, it can be said that the role of the Indonesian National Police Forensic Laboratory faces a problem that is so complex, that its implementation is not going well. Thus it will have a negative impact on the operation of a criminal justice system in creating legal processes in accordance with the provisions of the applicable laws and regulations in the present especially in the future that are not based on justice values, therefore it is very necessary to reconstruct the role of the Forensic Laboratory Indonesian National Police in the criminal justice system based on the value of justice.

Based on the condition of the problem which has been largely inventoried above, the limitation of the discussion of the problem in this study can be formulated as follows:

1. How is the role of the Indonesian National Police Forensic Laboratory in the Indonesian criminal justice system?

2. What are the weaknesses in the implementation of the role of the Indonesian National Police forensic Laboratory in the criminal justice system currently in Indonesia? 
3. How is the legal reconstruction of the role of the Indonesian National Police Forensic Laboratory in the criminal justice system based on justice values?

\section{Method of Research:-}

The research in writing this Article is normative juridical. The Writing aims to provide an overview. about a particular society or group of people or a description of a symptom or between two or more symptoms. Furthermore, this research seeks to explain the postulates studied in full in accordance with the findings in the field, then analyze the problem and find new ideas that may help solve the problem.

\section{Research Result and Discussion:-}

The role of the Indonesian National Police Forensic Laboratory in the Indonesian criminal justice system

The word forensic comes from the Latin word from the forum, meaning as a public meeting place in cities in ancient Roman times which are generally used for trade or other interests including a trial. While the meaning of the forum itself is a method of debate in public and matters that are part. For details, we can see what was stated by Susetio Pramusinto as follows :

"Forensics is science that uses multi-disciplinary science to apply natural science, chemistry, medicine, biology, psychology and criminology with the aim of making light in order to prove the existence of a crime / violation case by examining evidence or physical evidence in the case."

The definition of forensic laboratory referred to in this paper is an implementation of the high center of the Indonesian National Police Headquarters in the form of a body tasked and obliged to carry out criminal functions and carry out all service efforts and activities to assist in proving a criminal offense that occurs using technology and judicial medicine, forensic science, forensic chemistry and other supporting sciences.Based on this understanding, the forensic laboratory as one of the functions of the police which is an element of criminalistic laboratory technical assistance in the framework of the Indonesian National Police's task as an investigator.

Forensic laboratories in Indonesia have a big role in the development of the Indonesian police. The birth of a Forensic Laboratory in Indonesia is inseparable from the history of the founding of NCB / Interpol. Where in May 1952, two delegates from the Attorney General's Office and the State Police Department attended the 21st session of the ICPO / Interpol General Assembly as observers and in the same year Indonesia decided to become a member of ICPO / Interpol. As a condition of accepting Indonesian National Police to become a member of Interpol, one of which is that Indonesia must have applied or used Forensic Science. With the appointment of DKN as the Indonesian National Central Bureau (NCB Indonesia) on January 15, 1954 with the order of the Head of State Police Number: 1 / VIII / 1954, the Interpol Section and Laboratory Section were formed, under the Criminal Investigation Service. And the Laboratory Section at that time was tasked with examining letters / documents and firearms / ballistics examinations. On April 16, 1957 the Surabaya Branch of the Criminal Laboratory was established with Decree of the Head of the State Police Number: 26 / Lab / 1957 and placed administratively under the Office of the East Java Commissariat. And by working with the DepkesPharmasi Depot in Surabaya and the morgue at Dr. Hospital Soetomo Surabaya began the activities of laboratory scientific examination in the field of chemistry.

To tackle crimes that utilize science and technology as mentioned above can only be overcome by utilizing science and technology as well. The process of crime investigations using technology commonly referred to as scientific investigations or "scientific crime investigation / SCI scientific investigation) where the role and function is partly carried out by the Forensic Laboratory. And the "term" scientific crime investigation has been tested in the process of disclosing cases using science and technology.

Based on the current condition of the Indonesian National Police Forensic Laboratory, its role in the criminal justice system is not yet based on the value of justice, although its existence is very significant to the support of scientific evidence both at the investigation level and the level of proof at the hearing (supported by the data of each Indonesian National Police Forensic Laboratory the Semarang, Surabaya and Palembang branches in examining evidence at the TKP and at the Laboratory, which are marked by data on the number of case settlements from the investigator, as well as experts / expert witnesses at trials which are relatively large in intensity), while in general are still not based on fairness values, Dominant factors that influence are; substance elements, structural elements and cultural elements, from the results of interviews with heads of subdivisions within the Indonesian National Police Forensic Laboratory Semarang Branch, Surabaya Branch and Palembang Branch, all give the same information, 
namely that the Indonesian National Police Forensic Laboratory is still less well known or understood by the public and the Indonesian National Police itself (cultural factor factors), why is that the main cause is less socialized, the cause of lack of socialization is because the structure of the Indonesian National Police Forensic Laboratory is still limited, throughout Indonesia there are 7 Indonesian National Police Forensic Laboratory bases (structural element factor), socialization efforts have been carried out at each Indonesian National Police Forensic Laboratory according to the service area in the form of a scheduled coaching clinic, conducting vocational education and courses, receiving visits with guests from universities and institutions, workshops, seminars etc. but only a small percentage of the target being socialized, besides culture and structure factors are substance elements, in this element the main factor is the role of the Indonesian National Police Forensic Laboratory is not yet understand clearly by the investigator and even the investigator is not familiar with the parts of the Indonesian National Police Forensic Laboratory.

Suppose the investigators have understood and understood the role of the Indonesian National Police Forensic Laboratory but there are still other obstacles, especially the time and distance to empower the Indonesian National Police Forensic Laboratory because there are other agencies that can replace the position of the Indonesian National Police Forensic Laboratory, in substance KUHAP Article 184 (1) concerning evidence, the role of the Indonesian National Police Forensic Laboratory is the result of the examination of the Indonesian National Police Forensic Laboratory in the legal value of letters, expert statements and instructions, while the understanding of Experts and Letters is still multiple interpretations and thus will affect the role Indonesian National Police Forensic Laboratory itself in its role as evidence.

Weaknesses in the implementation of the role of the Indonesian National Police Forensic Laboratory in the Criminal Justice System

Weaknesses that arise in the implementation of the role of the Indonesian National Police Forensic Laboratory in the criminal justice system currently in Indonesia are :

1. From the data obtained through interviews with the examiners of the Indonesian National Police Forensic Laboratory as well as secondary data that support this study, it is obtained an analysis of weaknesses that arise, namely weaknesses in the substance, because understanding of the evidence contained in the evidence and expert statements is still multiple interpretations so that the empowerment of the Indonesian National Police Forensic Laboratory is not as it should be so that cases that should require scientific proof support from the Indonesian National Police Forensic Laboratory are not utilized as a result the cases that occur are not guaranteed legal certainty so that the value of justice is not fulfilled.

2. Likewise, based on the analysis, it was found that there was a large potential for weaknesses in the structural elements, because the number of Indonesian National Police Forensic laboratories throughout Indonesia was only 7 (seven), while there were 34 (thirty four) regional police stations, not to mention other big cities, so resulting in potential criminal cases not / not yet supported by scientific evidence is very large, consequently criminal acts that are not supported by scientific evidence, then cases that occur are not guaranteed legal certainty resulting in not fulfilling the value of justice.

3. The results of the next analysis are weaknesses in the culture element, because the Indonesian National Police Forensic Laboratory has not been maximally empowered, what happens is that cases which should have scientific support are not supported, so that cases that occur are not guaranteed legal certainty so that the cases that occur have not been fulfilled fair value.

Reconstruction of the Role of the Indonesian National Police Forensic Laboratory in the Justice-Based Criminal Justice System:

Based on the theory of justice, legal certainty, the legal system, the operation of the law, law enforcement and proof theory and forensic comparisons in various countries as well as the results of research in the field, the Reconstruction of the role of the Indonesian National Police forensic laboratory in a criminal justice system based on justice values is to realize evidence in a manner scientifically in a criminal case in court with the aim of obtaining legal certainty and fair values of justice. Based on the reconstruction, the authors are of the opinion that the renewal of the laws and regulations that are fair has an impact on justice, legal certainty and expediency.

The legal reconstruction of the role of the Indonesian National Police forensic laboratory in the criminal justice system based on the value of justice is as follows:

\begin{tabular}{|l|l|l|l|}
\hline No & Before Reconstruction & Reconstruction & Weakness \\
\hline
\end{tabular}




\begin{tabular}{|c|c|c|c|}
\hline 1 & $\begin{array}{l}\text { Element Substance : } \\
\text { Article } 184 \text { (1) of Act } 8 \text { of } 1981 \text { on } \\
\text { the Law of occasions Criminal . } \\
\text { Reads Tool proof that valid is : } \\
\text { 1. Description of witnesses } \\
\text { 2. Expert Information } \\
\text { 3. Letters } \\
\text { 4. Instructions } \\
\text { 5. Defendant's statement ( } 5 \text { items ) }\end{array}$ & $\begin{array}{l}\text { Article } 184 \text { (1) of Act } 8 \text { of } 1981 \\
\text { on the Law of occasions Criminal } \\
\text {. Reads Equipment evidence that } \\
\text { legitimate into } 6 \text { ( six ) are : } \\
\text { 1. Description of witnesses } \\
\text { 2. Expert Information } \\
\text { 3. Letters } \\
\text { 4. Instructions } \\
\text { 5. Defendant's statement } \\
\text { 6. Forensic Laboratory } \\
\text { Examination Results }\end{array}$ & $\begin{array}{l}\text { The results of the examination } \\
\text { of laboratory Forensics as a } \\
\text { means of evidence in the form } \\
\text { of testimony of experts and } \\
\text { letters are multiple } \\
\text { interpretations }\end{array}$ \\
\hline 2 & $\begin{array}{l}\text { Structure Elements : } \\
\text { When this newly formed base } \\
\text { Laboratory of Forensic Indonesian } \\
\text { National Police as much as } 7 \text { ( seven ) } \\
\text { base. }\end{array}$ & $\begin{array}{l}\text { In every police there are bases lab } \\
\text { Forensic even also in there in the } \\
\text { big cities. }\end{array}$ & $\begin{array}{l}\text { Services are very limited, so the } \\
\text { implementation is on a priority } \\
\text { scale so that other cases have } \\
\text { not received forensic services. }\end{array}$ \\
\hline 3 & $\begin{array}{l}\text { Cultural Elements : } \\
\text { Investigators are still not empowering } \\
\text { the Forensic Laboratory and } \\
\text { information about forensics is less } \\
\text { than optimal }\end{array}$ & $\begin{array}{l}\text { Forensic } \\
\text { Empowerment is maximized , } \\
\text { socialization will be automatic } \\
\text { because of the Forensic } \\
\text { Laboratory Examination Results } \\
\text { Being } 6 \text { ( six) items contained in } \\
\text { the Criminal Code that will be } \\
\text { read and understood by the } \\
\text { practitioners of law as well as } \\
\text { among academics }\end{array}$ & $\begin{array}{l}\text { Most of the Case criminal is not } \\
\text { proven by science through the } \\
\text { Laboratory of Forensic. }\end{array}$ \\
\hline
\end{tabular}

\section{Conclusion:-}

1. In general, the factors influencing the role of the Indonesian National Police forensic Laboratory in the criminal justice system that are not currently based on justice values are: Substance elements, in the KUHAP substance Article 184 (1) concerning evidence, the role of the Indonesian National Police forensic Laboratory is located on the results of the examination of the Indonesian National Police forensic Laboratory in the legal value as evidence in the form of letters, expert statements and instructions, as for the understanding of experts and letters are still multiple interpretations thus will affect the role of the Indonesian National Police forensic Laboratory, then the structural elements, the role of the Laboratory Indonesian National Police forensics is still poorly known or understood by the community and the Indonesian National Police itself, the main cause is lack of socialization, the cause of lack of socialization is due to the structure at the construction of the Indonesian National Police forensic Laboratory base still limited, throughout Indonesia there are only 7 (seven) Indonesian National Police forensic laboratories and cultural element factors, that the role of the Indonesian National Police Forensic laboratories is still poorly known or understood by the public and the Indonesian National Police itself especially investigators, if investigators already understand all the spaces the scope of the Indonesian National Police Forensic Laboratory but due to the distance and time factors (structural factors which are currently only being built by seven forensic laboratories) the investigator uses other agencies that are considered to be able to replace the role of the Indonesian National Police Forensic Laboratory, other common factors from aspects of cultural elements are sources human resources both at investigators and examiners of the Indonesian National Police Forensic Laboratory, the understanding of formal and technical handling is still uneven, in addition to infrastructure factors, special instruments that supporting it are not adequate.

2. Weaknesses that arise in the implementation of the role of the Indonesian National Police forensic Laboratory in the criminal justice system at this time are not yet based on the value of justice in general are: Weaknesses in the substance element, because the understanding of the evidence contained in the evidence and letter of expert evidence is still multiple interpretations so the empowerment of the Indonesian National Police forensic Laboratory is not as it should be so that cases that should require scientific proof support from the Indonesian National Police forensic Laboratory are not utilized as a result the cases that occur are not guaranteed legal 
certainty by not meeting the value of justice then weaknesses in the structural elements, due to the number of forensic laboratories Indonesian National Police have throughout Indonesia only have 7 (seven), as for the number of Polda there are 34 (thirty-four) not to mention other big cities, resulting in potential criminal cases not / not yet registered Due to scientific evidence is very large, as a result of criminal acts that are not supported by scientific evidence, the cases that occur are not guaranteed legal certainty which results in not fulfilling the value of justice and weaknesses in the cultural elements, because the Indonesian National Police forensic Laboratory has not been maximally empowered then the what happens is a case that should be supported by scientific evidence is not supported, so that the case that occurs is not guaranteed legal certainty so that the case that occurs has not been met the value of justice.

3. The legal reconstruction of the role of the Indonesian National Police Forensic Laboratory in the criminal justice system based on the value of justice is as follows:Reconstruction of the substance of substance in Article 184 (1) of Law No.8 of 1981 concerning Criminal Procedure Code, reads legal evidence into 6 (six) items, which are witness statements, expert statements, letters, instructions, statements of the accused and the results of the examination Forensic laboratories, while reconstruction of structural elements is in every Polda built Indonesian National Police forensic laboratories even in large cities and reconstructing cultural elements: Empowering forensic laboratories, with the "Forensic Laboratory Examination Results" strategy included in item to 6 (six) to Evidence, Article 184 (1) Criminal Procedure Code.

\section{References:-}

1. Abdussalam, 2006. Forensik. Restu Agung, Jakarta.

2. Alvian Solar.2012.Hakikat Dan Prosedur Pemeriksaan Tindak Pidana Ringan, Lex Crimen, Vol.I/No.1/Jan$\mathrm{Mrt} / 2012$.

3. Bandik. 2000.Pengenalan Kedokteran Forensik. Akpol. Semarang.

4. D. Sudjono. 1976. Kriminalistik dan Ilmu Forensik, Bandung: Tribisana Karya.

5. Firganefi dan Ahmad Irzal Fardiansyah.2014. Hukum dan Kriminalistik. Bandar Lampung: BP.Justice Publisher.

6. Giannelli, Paul C., "Independent Crime Laboratories: The Problem of Motivational and Cognitive Bias" (2010). Faculty Publications. 603. https://scholarlycommons.law.case.edu/faculty_publications/603

7. Hadi, Sutrisno.1996. Metodologi Research, (edisikesepuluh), Yogyakarta: Andi Offset

8. Indries, A. M.2008. Penerapan Ilmu Kedokteran Forensik Dalam Proses Penyidikan. SagungSeto, Jakarta.

9. Susetio Pramusinto,1984,Himpunan karangan ilmu forensik, Karya Unipress, Jakarta.

10. Wahyu Widodo, Sapto Budoyo and Toebagus Galang Windi Pratama, 2018. The Role of Law Politics on Creating Good Governance and Clean Governance for a Free-Corruption Indonesia in 2030. The Social Sciences, 13: 1307-1311.

11. Waluyo, Bambang. 1996. Sistem Pembuktian Dalam Peradilan Indonesia. Jakarta: SinarGrafika. 